\title{
Posterior reversible encephalopathy syndrome as the first manifestation of mixed connective tissue disorder: a case report
}

\author{
Phani Krishna Machiraju ${ }^{1,3^{*}}$, Neetu Mariam Alex ${ }^{1}$ Safinaaz ${ }^{1}$ and Sriram Sankaran²
}

\begin{abstract}
Background: Posterior reversible encephalopathy syndrome (PRES) is a neurological syndrome characterised by a range of neurological symptoms and signs, and distinctive neuroimaging findings reflecting vasogenic oedema. Posterior reversible encephalopathy syndrome has been described in association with many autoimmune diseases, but its association with mixed connective tissue disorder (MCTD) is very rare. After an extensive review of the literature, we found only three cases of posterior reversible encephalopathy syndrome in association with mixed connective tissue disorder. But unlike other cases, in our patient, PRES is the presenting manifestation of mixed connective tissue disorder which is first of its kind.
\end{abstract}

Case presentation: We present a 30-year-old female from Southern India who had initially reported with complaints of fever, multiple episodes of vomiting and cough with expectoration. She had accelerated hypertension and moderate thrombocytopenia. Two days later, she developed sudden onset of visual disturbances and had a drop in sensorium. Neuroimaging done was suggestive of atypical posterior reversible encephalopathy syndrome, and autoimmune workup was positive for mixed connective tissue disorder. With prompt blood pressure control and anti-seizure medications, she recovered completely.

Conclusion: Early diagnosis and prompt control of blood pressure, along with anti-seizure measures, play a crucial role in management. Awareness about this rare association is essential for early diagnosis and treatment, and therefore reducing the risk of permanent neurologic deficits. This case is being reported because of its rarity.

Keywords: Atypical PRES, MCTD, Mixed connective tissue disorder, Autoimmune diseases

\section{Background}

Posterior reversible encephalopathy syndrome (PRES) is defined by a range of neurological symptoms of acute onset, focal vasogenic oedema on neuroimaging and reversibility of clinical and radiological findings [1]. Its causes are diverse, but common precipitants include acute elevations of blood pressure, renal decompensation, fluid retention, and treatment with immunosuppressive

\footnotetext{
*Correspondence: phani940@gmail.com

${ }^{1}$ Department of General Medicine, Apollo Main Hospitals, Greams Road, Chennai, Tamil Nadu 600006, India
}

Full list of author information is available at the end of the article drugs [2]. The symptoms of PRES evolve rapidly over hours to days. Early diagnosis and prompt control of blood pressure along with anti-seizure measures play a key role in the management and outcome of the case, by preventing further brain damage. PRES has been described in association with many autoimmune diseases, but its association with mixed connective tissue disorder (MCTD) is very rare. In this report, we describe a case of PRES in a young female who was subsequently diagnosed to have MCTD. original author(s) and the source, provide a link to the Creative Commons licence, and indicate if changes were made. The images or other third party material in this article are included in the article's Creative Commons licence, unless indicated otherwise in a credit line to the material. If material is not included in the article's Creative Commons licence and your intended use is not permitted by statutory regulation or exceeds the permitted use, you will need to obtain permission directly from the copyright holder. To view a copy of this licence, visit http://creativecommons.org/licenses/by/4.0/. The Creative Commons Public Domain Dedication waiver (http://creativeco mmons.org/publicdomain/zero/1.0/) applies to the data made available in this article, unless otherwise stated in a credit line to the data. 


\section{Case presentation}

Our patient was a 30-year-old female from Southern India who had initially reported to a local general practitioner with complaints of fever, multiple episodes of vomiting and cough with expectoration for 5 days. She was treated with oral antibiotics (amoxicillin/clavulanic acid $625 \mathrm{mg}$ oral twice daily), but she continued to have fever spikes (mild to moderate grade with Tmax of $102.6^{\circ} \mathrm{F}$ ).
On admission and evaluation in a local hospital, she was diagnosed to have accelerated hypertension $(200 / 110$ $\mathrm{mm}$ of hg), moderate thrombocytopenia $\left(60,000 / \mathrm{mm}^{3}\right)$. While she was being managed with intravenous fluids and antihypertensive medications (labetalol $2 \mathrm{mg} / \mathrm{min}$ intravenous infusion), she developed sudden onset of visual disturbances and had a drop in sensorium. Computed Tomography scan brain revealed ill-defined areas

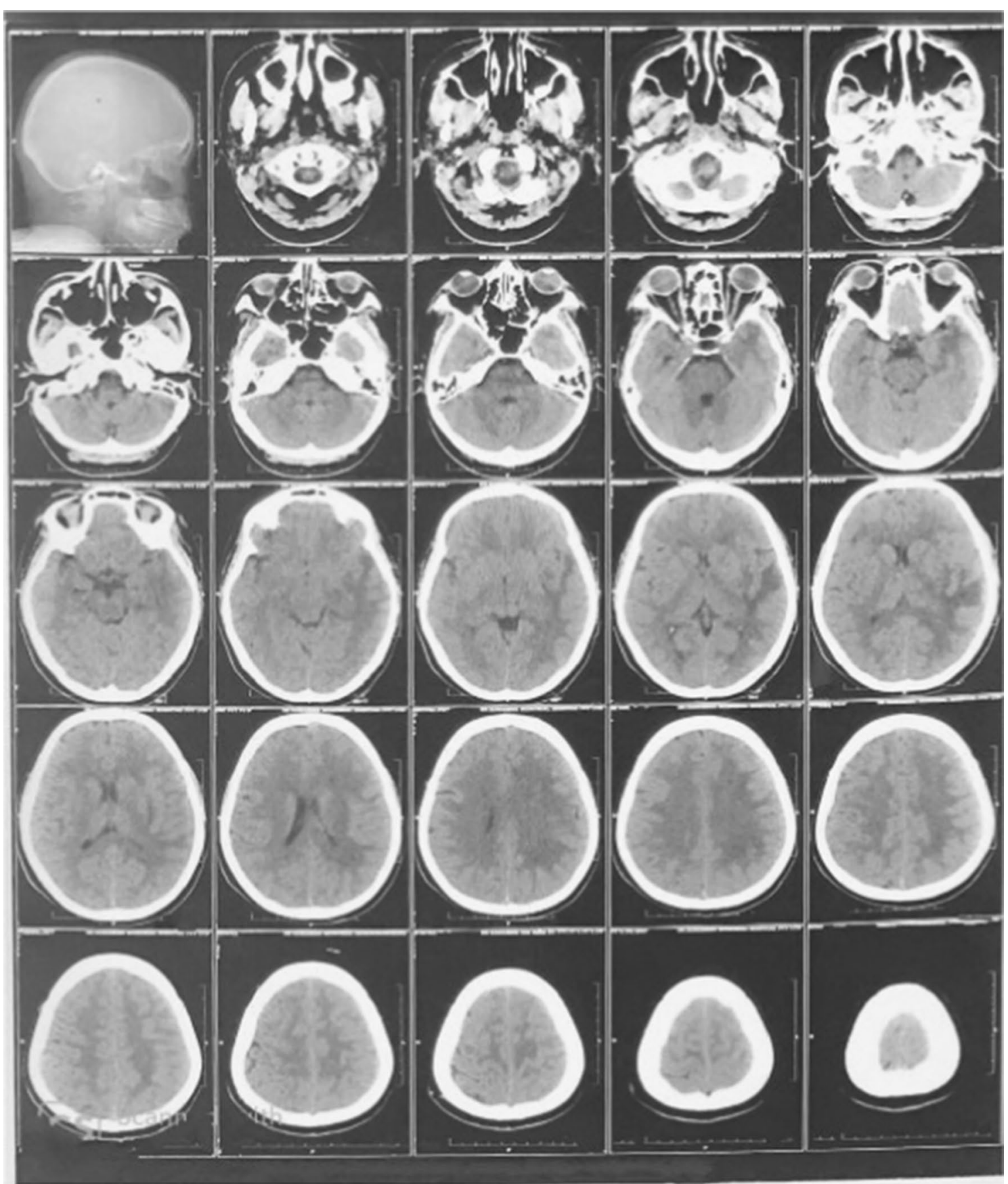

Fig. 1 Computed Tomography (CT) scan. Brain showing ill-defined areas of parenchymal Edema in left parieto temporal lobe 
of parenchymal oedema in left parieto-temporal lobe white matter, left ganglio-capsular and left hippocampal regions (Fig. 1).

Magnetic resonance imaging brain (Figs. 2, 3, 4) revealed ill-defined T2/ FLAIR hyperintense signals in left parieto temporal region, multiple small foci of restricted diffusion in the left frontoparietal, parasagittal region, multiple small patchy FLAIR hyperintense lesions were seen in bilateral frontoparietal subcortical white matter, left thalamus, bilateral basal ganglion, splenium of the corpus callosum on the left side and bilateral perioptic space widening with partial empty sella. All these features were suggestive of atypical PRES or acute demyelinating encephalomyelitis.

She was treated with anti-epileptics (levetiracetam 500 mg twice daily), antihypertensive medications (labetalol $100 \mathrm{mg}$ twice daily oral) and glucocorticoids (methylprednisolone $500 \mathrm{mg}$ intravenously for 1 day). She was shifted to our hospital for further management. Her past medical history was notable for an aborted twin pregnancy and gestational hypertension about three years ago. She denied a history of any other co-morbidity. Her family history and psychosocial history was unremarkable. Physical examination was notable for pallor, tachycardia, and elevated blood pressure (190/100). She was drowsy but arousable with Glasgow coma scale/score of 14/15 (E3V5M6) at the time of admission. Neurological examination was notable for bilateral extensor plantar response. Cranial nerves, motor, sensory and other deep tendon reflexes examination were normal. Baseline blood investigations were notable for anaemia (Haemoglobin $-8.2 \mathrm{~g} / \mathrm{dl}$ ), moderate thrombocytopenia (platelet

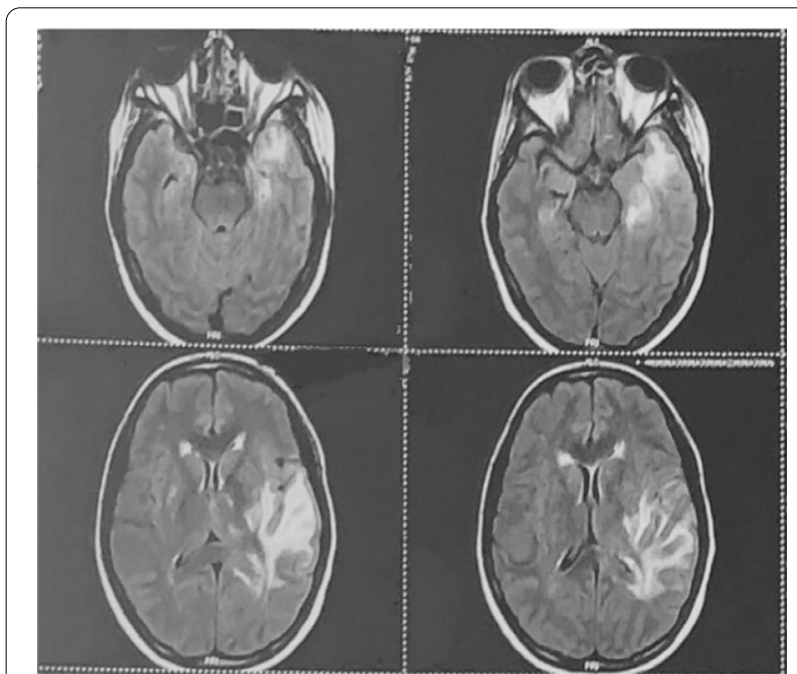

Fig. 2 Magnetic resonance imaging (MRI). Brain with features suggestive of Atypical PRES count $-51,000 / \mathrm{mm}^{3}$ ), and mild hypokalemia (serum $\mathrm{K}+-3.1 \mathrm{meq} / \mathrm{l})$.

Blood and urine cultures were sent, and she was started on empirical antibiotics (ceftriaxone $2 \mathrm{~g}$ twice-daily intravenous and oral doxycycline $100 \mathrm{mg}$ twice daily), antihypertensives (labetalol $2 \mathrm{mg} / \mathrm{min}$ infusion followed by $100 \mathrm{mg}$ twice daily oral) and anti-epileptics (levetiracetam $500 \mathrm{mg}$ orally twice daily). Infective workup done was negative (Dengue, malarial parasite (quantitative buffy coat test), H1N1 polymerase chain reaction test and Scrub typhus IgM enzyme-linked immunosorbent assay test). Guarded lumbar puncture was done to rule out infective causes of encephalomyelitis after discussing with the neurologist and infectious diseases specialist. Cerebrospinal fluid analysis (CSF) was noncontributory. (CSF was colourless, clear, no red blood cells or white blood cells were seen, Glucose was $64 \mathrm{mg} /$ $\mathrm{dl}$, protein was $41.1 \mathrm{mg} / \mathrm{dl}$, GeneXpert MTB/RIF assay, Herpes simplex virus $1 \& 2$ real time polymerase chain reaction test were negative and CSF culture did not show any significant growth). Blood and urine cultures did not show any significant growth. Antiphospholipid antibody syndrome workup was negative. Antinuclear antibody by indirect immunofluorescence assay was positive (1:40 dilution, Intensity-4+, pattern nuclear coarse speckled). Anti-double-stranded DNA was negative, and extractable nuclear antigen antibodies profile was positive for $\mathrm{Sm} / \mathrm{RNP}$ and negative for $\mathrm{Sm}$. She was finally diagnosed to have posterior reversible encephalopathy syndrome (PRES) with underlying mixed connective tissue disorder. She recovered completely with antihypertensives (T. Metoprolol XL 25 mg PO BD) and anti-epileptics (T. Levetiracetam $500 \mathrm{mg}$ PO BD). Repeat platelet count done on Day 4 of admission was normal (2, 64,000 cells/ $\mathrm{mm}^{3}$ ). She was discharged with a plan to continue antihypertensive medications (T. Metoprolol XL $25 \mathrm{mg}$ oral twice daily). She was reviewed as an outpatient after 6 weeks, and she was doing well. Follow-up MRI of Brain done after six weeks as outpatient showed resolution of oedema (Fig. 5). After discussing with patient and family in detail, our plan, in this case, was strict blood pressure control, watch out for MCTD manifestations by regular follow up.

\section{Discussion}

Posterior reversible encephalopathy syndrome (PRES) was first described by Hinchey and his colleagues as Reversible posterior leukoencephalopathy syndrome, in a series of 15 patients in 1996 [2]. PRES is characterised by neurological manifestations of acute onset headache, visual disturbances, seizures, altered sensorium; vasogenic oedema on neuroimaging mostly in the posterior regions and reversibility of clinical and imaging findings. 


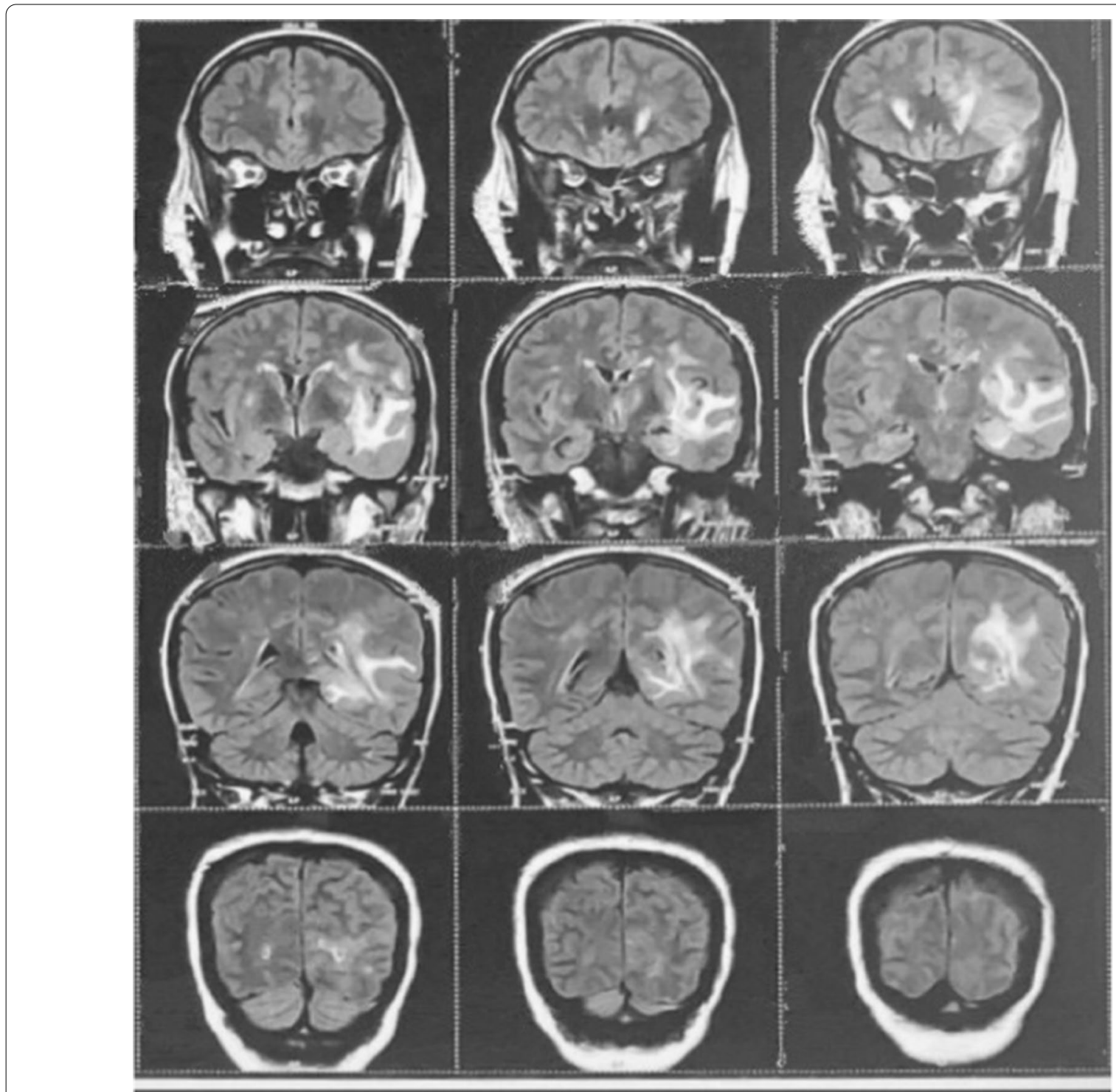

Fig. 3 Magnetic resonance imaging (MRI). Brain with features suggestive of Atypical PRES

Women are more commonly affected than men, even after excluding eclampsia as a cause. Our patient was a young female.

PRES most commonly presents as subcortical oedema in parieto-occipital areas. Other atypical regions that may be affected include deep gray nuclei, brainstem/ cerebellar hemispheres, and exceptionally the spinal cord without cerebral hemispheric involvement. These findings may lead to a diagnostic dilemma, with a delay in diagnosis and reversal of the offending condition potentially leading to a poor patient outcome [3]. In our patient, subcortical oedema was seen in the frontoparietal and parieto-temporal region, which is atypical of PRES.
PRES is associated with hypertension, renal failure and eclampsia, in patients receiving immunosuppressive therapy, chemotherapy and in patients with underlying autoimmune disease [4]. Though many autoimmune disorders like systemic lupus erythematosus, polyarteritis nodosa, granulomatosis with polyangiitis, cryoglobulinemia have been described in association with PRES, its association with MCTD is very rare. Neurological involvement as such is rare in MCTD as compared with other system involvement. It more commonly manifests as trigeminal neuralgia, aseptic meningitis and headache. After an extensive review of the literature, we found only three case reports till now of this rare association, as 


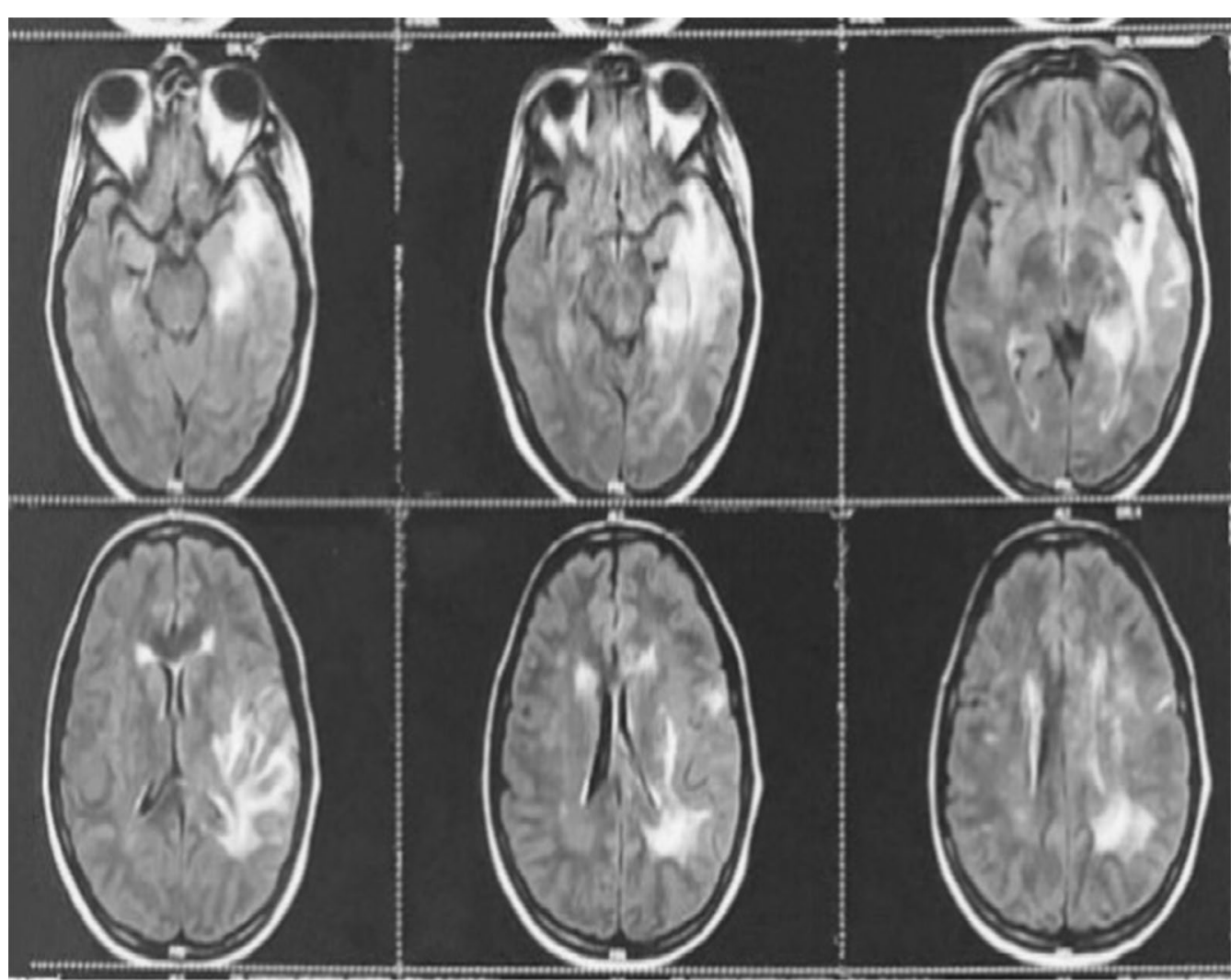

Fig. 4 Magnetic resonance imaging (MRI). Brain with features suggestive of Atypical PRES

described in Table 1 [4-6]. All the cases reported till now are between 15 and 30 years of age.

Possible pathological mechanisms that could result in PRES with the background of MCTD include endothelial cell damage resulting from different autoantibodies in MCTD, vasculopathy and autonomic dysfunction [5].

Treatment for PRES is mainly aimed at blood pressure control, anti-seizure measures and other supportive measures. Blood pressure should be managed with easily titratable medications like intravenous labetalol, nitroprusside and nicardipine etc. The rapid decrease in blood pressure could cause cerebral ischemia, which is why a goal of mean blood pressure between 105 and $125 \mathrm{mmHg}$ is suggested, without exceeding $25 \%$ of this reduction in the first hour [6]. As with other conditions, blood pressure fluctuations should be avoided, and the continuous administration of antihypertensive drugs under hemodynamic monitoring should be considered [1]. In our patient, we managed her blood pressure with parenteral labetalol followed by oral medications and also with antiepileptic mediations. PRES is the first presentation of MCTD in our patient, unlike the other reported cases till now.

\section{Conclusion}

Cases of PRES have been increasingly reported off late. It has been described to be associated with various etiopathological factors, including autoimmune conditions, but its association with MCTD is very rare. Treatment depends mainly on the underlying pathology and outcome depends on early diagnosis and treating the underlying condition. Awareness about this rare association is crucial for early diagnosis and treatment, and therefore reducing the risk of permanent neurologic deficits. Autoimmune disorders like MCTD should be considered as one of the differential diagnosis in a 


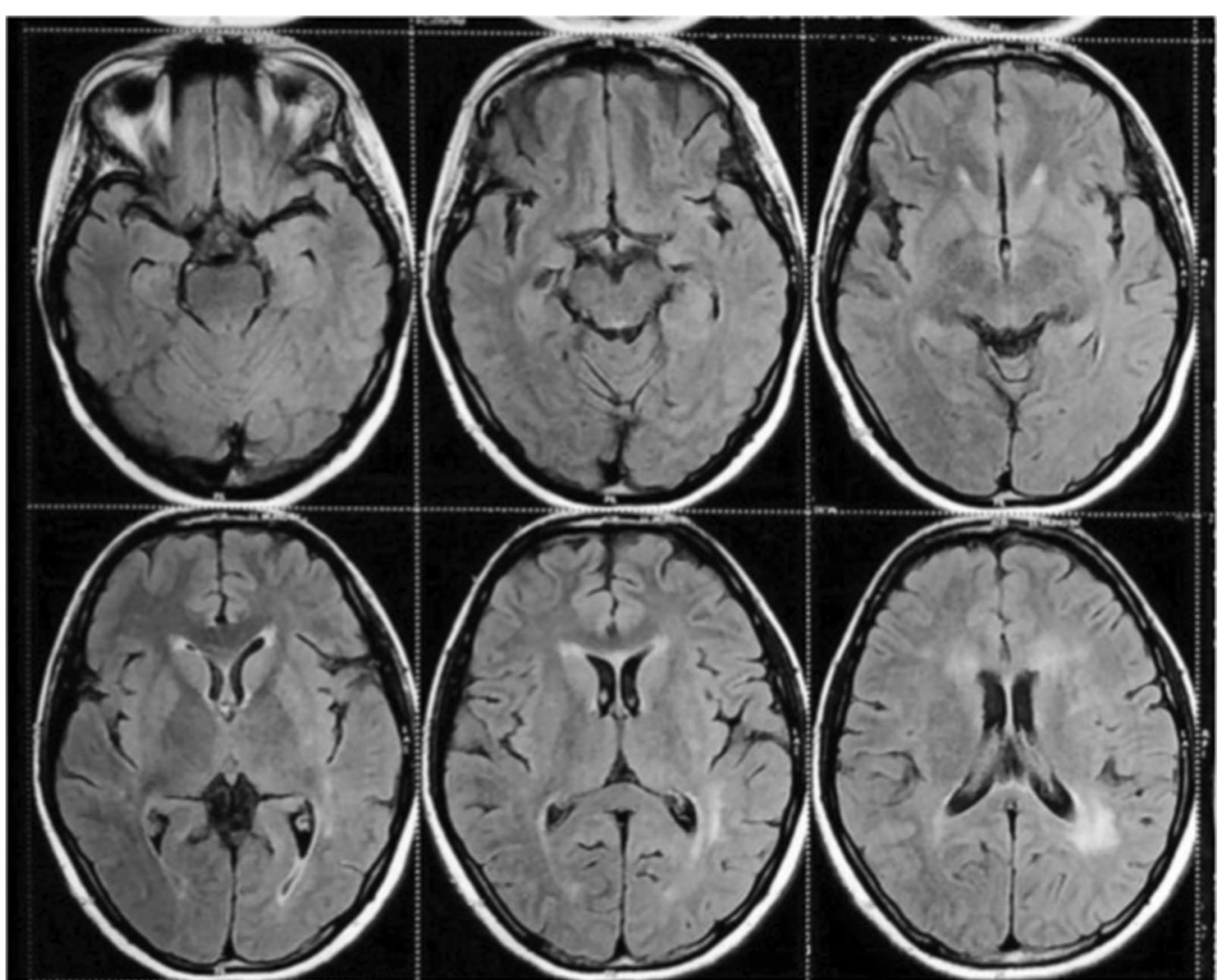

Fig. 5 Follow-up MRI brain showing. Resolution of oedema

Table 1 Case reports of PRES with MCTD reported till now

\begin{tabular}{|c|c|c|c|c|c|c|c|}
\hline Case & Age & Sex & $\begin{array}{l}\text { Associations/ } \\
\text { Medications }\end{array}$ & Hypertension & Clinical features & MRI findings & Outcome/sequale \\
\hline Case-1 & 15 years & Male & $\begin{array}{l}\text { Mixed connective tissue } \\
\text { disease on cyclo- } \\
\text { phosphamide pulse } \\
\text { therapy, prednisolone } \\
\text { and HCQ }\end{array}$ & Yes & GTCS & $\begin{array}{l}\text { High signal intensities in } \\
\text { the posterior areas of } \\
\text { his brain. }\end{array}$ & $\begin{array}{l}\text { Uncontrollable res- } \\
\text { piratory distress and } \\
\text { eventually died }\end{array}$ \\
\hline Case-2 & 20 years & Female & $\begin{array}{l}\text { Mixed connective tissue } \\
\text { disease }\end{array}$ & No & $\begin{array}{l}\text { Headache and intermit- } \\
\text { tent vomiting along } \\
\text { with two episodes of } \\
\text { GTCS }\end{array}$ & $\begin{array}{l}\text { Bilateral hyper } \\
\text { intense signal in } \\
\text { occipital region on } \\
\text { T2 weighted MRI and } \\
\text { FLAIR, and bilateral } \\
\text { hypo intense signal in } \\
\text { T1 weighted MRI }\end{array}$ & $\begin{array}{l}\text { Completely recov- } \\
\text { ered. Follow up MRI } \\
\text { Brain was normal }\end{array}$ \\
\hline Case-3 & 12 years & Male & $\begin{array}{l}\text { Mixed connective tissue } \\
\text { disease, secondary } \\
\text { membranous glo- } \\
\text { merulopathy }\end{array}$ & No & $\begin{array}{l}\text { GTCS } \\
\text { Aphasia } \\
\text { Fever } \\
\text { Generalized body } \\
\text { swelling }\end{array}$ & $\begin{array}{l}\text { Hyper intense signal in } \\
\text { the parieto-occipital } \\
\text { regions }\end{array}$ & Completely recovered \\
\hline Our patient & 30years & Female & $\begin{array}{l}\text { Mixed connective tissue } \\
\text { disease }\end{array}$ & Yes & $\begin{array}{l}\text { Headache } \\
\text { Fever } \\
\text { Visual disturbances } \\
\text { Sudden drop in sen- } \\
\text { sorium }\end{array}$ & $\begin{array}{l}\text { Hyperintense signals } \\
\text { in fronto parietal and } \\
\text { parieto temporal } \\
\text { region }\end{array}$ & Completely recovered \\
\hline
\end{tabular}


young female presenting with accelerated hypertension and acute onset neurological symptoms suggestive of posterior reversible encephalopathy syndrome.

\section{Abbreviations}

MCTD: Mixed connective tissue disease; PRES: Posterior reversible encephalopathy syndrome; CSF: Cerebrospinal fluid.

\section{Acknowledgements}

The authors thank the family of the patient for their assistance in preparing the manuscript.

\section{Authors' contributions}

All the authors prepared the manuscript and collected all data and suitable references. All authors read and approved the final manuscript.

\section{Funding}

Nil.

\section{Availability of data and materials}

Not applicable.

\section{Ethics approval and consent to participate}

As per our institutional ethics committee guidelines we do not require ethics approval for case reports.

\section{Consent for publication}

Written informed consent was obtained from the patient for publication of this case report and any accompanying images. A copy of the written consent form is available for review by the Editor-in-Chief of this journal.

\section{Competing interests}

The authors declare that they have no competing interests.

\section{Author details}

${ }^{1}$ Department of General Medicine, Apollo Main Hospitals, Greams Road, Chennai, Tamil Nadu 600006, India. ${ }^{2}$ Department of Rheumatology, Apollo Main Hospitals, Greams Road, Chennai, Tamil Nadu 600006, India. ${ }^{3}$ Nellore, Andhra Pradesh 524002, India.
Received: 15 May 2020 Accepted: 11 January 2021

Published online: 02 February 2021

\section{References}

1. Fischer M, Schmutzhard E. Posterior reversible encephalopathy syndrome. J Neurol. 2017;264:1608-16.

2. Hinchey J, et al. A reversible posterior leukoencephalopathy syndrome. $N$ Engl J Med. 1996;334:494-500.

3. Saad AF, Chaudhari R, Wintermark M. Imaging of atypical and complicated posterior reversible encephalopathy syndrome. Front Neurol. 2019;10:964.

4. Das M, et al. Posterior reversible encephalopathy syndrome in a patient with underlying mixed connective tissue disease. Int J Res Med Sci. 2018;6(7):2551-3.

5. Rahmanzadeh $\mathrm{R}$, et al. Posterior reversible encephalopathy syndrome in a patient with mixed connective tissue disease: a case report. J Med Case Rep. 2016;10:145.

6. Khan K, Qureshi S. Posterior reversible encephalopathy syndrome in a 12-year-old boy with mixed connective tissue disease. Ann Infect Dis Epidemiol. 2019:4(2):1041.

7. Fuseau Herrera M, Villagomez Estrada M, Garrido Salazar D, Noba Torres D, Escudero Abad L, Navarezcastillo B. Diagnosis and management of posterior reversible encephalopathy syndrome in Systemic lupus Erythematosus. Rev colomb Rheumatol. 2019:26:74-9.

\section{Publisher's Note}

Springer Nature remains neutral with regard to jurisdictional claims in published maps and institutional affiliations.
Ready to submit your research? Choose BMC and benefit from

- fast, convenient online submission

- thorough peer review by experienced researchers in your field

- rapid publication on acceptance

- support for research data, including large and complex data types

- gold Open Access which fosters wider collaboration and increased citations

- maximum visibility for your research: over 100M website views per year

At $\mathrm{BMC}$, research is always in progress.

Learn more biomedcentral.com/submissions 